\title{
Docetaxel plus ramucirumab with primary Pesearch Paper pegylated-granulocyte-colony stimulating factor for pretreated non-small cell lung cancer
}

\author{
Akito Hata1 ${ }^{1}$, Daijiro Harada ${ }^{3}$, Chiyuki Okuda ${ }^{1}$, Reiko Kaji ${ }^{1}$, Yoshio Masuda ${ }^{2}$, Yoshika \\ Takechi $^{4}$, Toshiyuki Kozuki $^{3}$, Naoyuki Nogami ${ }^{3}$ and Nobuyuki Katakami ${ }^{1}$ \\ ${ }^{1}$ Department of Medical Oncology, Kobe City Medical Center General Hospital, Kobe, Japan \\ ${ }^{2}$ Department of Pharmacy, Kobe City Medical Center General Hospital, Kobe, Japan \\ ${ }^{3}$ Department of Thoracic Oncology, National Hospital Organization Shikoku Cancer Center, Matsuyama, Japan \\ ${ }^{4}$ Department of Pharmacy, National Hospital Organization Shikoku Cancer Center, Matsuyama, Japan \\ Correspondence to: Akito Hata, email: akitohata@hotmail.com \\ Keywords: docetaxel; ramucirumab; febrile neutropenia; pegylated-granulocyte-colony stimulating factor \\ Received: March 22, $2018 \quad$ Accepted: May 21, $2018 \quad$ Published: June 12, 2018 \\ Copyright: Hata et al. This is an open-access article distributed under the terms of the Creative Commons Attribution License 3.0 \\ (CC BY 3.0), which permits unrestricted use, distribution, and reproduction in any medium, provided the original author and source \\ are credited.
}

\section{ABSTRACT}

Purpose: The aim of our study was to evaluate the efficacy and safety of docetaxel plus ramucirumab with primary prophylactic pegylated (PEG)-granulocyte-colony stimulating factor (G-CSF) for pretreated non-small cell lung cancer (NSCLC).

Results: Sixty-one pretreated NSCLC patients underwent docetaxel plus ramucirumab. Primary prophylactic PEG-G-CSF was performed in $52(85 \%)$ patients (prophylactic group). No febrile neutropenia (FN) $(0 \%)$ was confirmed in 52 prophylactic group patients, whereas FN was observed in 3 (33\%) of 9 nonprophylactic group patients. Among prophylactic group, median lines of prior therapy was 2 (range, 1-9). Median cycles of docetaxel plus ramucirumab was 3 (range, 1-25) ( 9 and 3 cases moved to ramucirumab and docetaxel monotherapies, respectively). Response rate and disease control rate were $30.8 \%$ and $73.1 \%$, respectively. Median progression-free survival was 4.5 (95\% confidence interval [CI], 3.0-6.6) months. Median overall survival was 11.4 (95\% CI, 8.0-13.9) months. Six (11.5\%) patients had grade $3 / 4$ neutropenia. Observed grade 3 (incidence $\geq 10 \%$ ) adverse event (AE) was oral mucositis $(13.5 \%)$. There were no grade 4/5 non-hematological AEs.

Conclusions: Our study demonstrated the efficacy and safety of docetaxel plus ramucirumab with PEG-G-CSF in clinical practice. Primary prophylactic PEG-G-CSF could markedly reduce incidence of $F N$.

Methods: We retrospectively reviewed medical records of pretreated NSCLC cases who had received docetaxel plus ramucirumab in our departments.

\section{INTRODUCTION}

Systemic chemotherapy is the standard treatment for metastatic advanced non-small cell lung cancer (NSCLC). Current revolutionally advancement of molecular targeted therapies and immunotherapies has improved prognosis of NSCLC patients. Epidermal growth factor receptor (EGFR)-tyrosine kinase inhibitors (TKIs) or anaplastic lymphoma kinase (ALK)-TKIs exhibited remarkable efficacies over platinum-doublet cytotoxic chemotherapies in patients harboring EGFR gene mutations or ALK gene fusions [1-5]. Furthermore, pembrolizumab, antiprogrammed death-1 (PD-1) antibody has demonstrated superior overall survival over platinum-doublets in first-line setting of NSCLC patients with PD-ligand 1 (PD-L1) tumor proportion score $\geq 50 \%$ [6]. Despite an 
initial dramatic response and durable progression-free survival (PFS) using these agents, progressive disease (PD) is inevitable in most patients. Therefore, second-line chemotherapy is still important to salvage patients after PD on a first-line chemotherapy.

Docetaxel was the standard regimen in secondline chemotherapy for pretreated NSCLC. Although a lot of agents, or those in combination with docetaxel, were compared to docetaxel monotherapy, no agents or combination therapies proved superior to docetaxel monotherapy. Eventually, immunotherapies with PD-1/ PD-L1 inhibitors such as nivolumab, pembrolizumab, and atezolizumab have shown superior survival benefit over docetaxel monotherapy [7-10]. These immunotherapies give a strong survival benefit to responders, but disease control rate is relatively low, and early death is a serious concern in non-responders [11].

Ramucirumab is a fully human immunoglobulin G1 monoclonal antibody that binds with high affinity to vascular endothelial growth factor (VEGF) receptor-2, preventing VEGF binding and activation [12]. A randomized, phase III REVEL trial demonstrated that additional ramucirumab to docetaxel prolonged OS in NSCLC patients who had progressed after firstline platinum-based therapy [13]. In this trial, superior response rate (RR) and PFS translated to OS benefit with a high disease control rate (DCR). A similarly designed Japanese randomized phase II trial comparing docetaxel plus ramucirumab with docetaxel monotherapy showed that effectiveness of additional ramucirumab was comparable to those of REVEL study [14]. On the other hand, a safety concern was suggested. Febrile neutropenia (FN) was confirmed in 34\% of these Japanese patients in docetaxel plus ramucirumab arm. This high incidence of FN presents an important clinical problem for docetaxel plus ramucirumab, used routinely in Japanese clinical practice.

The American Society of Clinical Oncology practice guideline recommends primary prophylactic granulocyte- colony stimulating factor (G-CSF) when the risk of FN is approximately $20 \%$ or higher [15]. We thus consider primary prophylactic G-CSF to be suitable in docetaxel plus ramucirumab therapy for Japanese patients. Pegylated (PEG)-G-CSF demonstrated reduction of FN incidence administered once a cycle in many types of cancers. PEG-filgrastim is a polyethylene glycol-derived form of filgrastim. Based on the features of PEG-conjugated proteins, PEG-filgrastim was designed to prolong the half-life of filgrastim and to decrease the number of injections. A Japanese double-blind, placebo-controlled, randomized phase III trial of PEG-filgrastim in 343 breast cancer patients receiving docetaxel and cyclophosphamide chemotherapy showed that the incidence of $\mathrm{FN}$ was significantly lower in the PEG-filgrastim group than in the placebo group $(1.2 \%$ vs. $68.8 \%, P<0.001)$ [16]. In NSCLC patients, incidence of FN could also be reduced by PEG-G-CSF.

Based on the above background, we actively use primary prophylactic PEG-G-CSF in our clinical practice on docetaxel plus ramucirumab therapy. The aim of this retrospective study was to evaluate the efficacy and safety of docetaxel plus ramucirumab with primary prophylactic PEG-G-CSF support for pretreated NSCLC in Japanese clinical practice.

\section{RESULTS}

\section{Patient characteristics}

Study flow chart is shown in Figure 1. Between June 2013 and April 2018, 61 pretreated NSCLC patients received docetaxel plus ramucirumab at our departments (31 Department of Medical Oncology, Kobe City Medical Center General Hospital [KCGH] and 30 Department of Thoracic Oncology, Shikoku Cancer Center [SCC]). We fully evaluated the efficacy and safety of docetaxel plus ramucirumab in $52(85 \%)$ patients receiving primary prophylactic PEG-G-CSF (prophylactic group). In

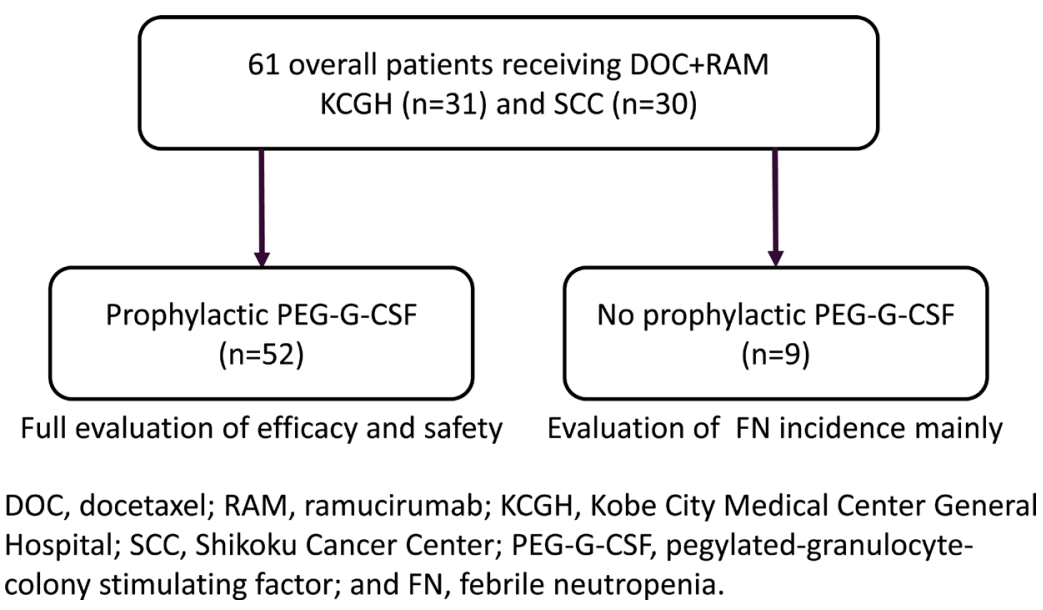

Figure 1: Study flow chart. 
Table 1: Patient characteristics

\begin{tabular}{|c|c|c|}
\hline Characteristics & Prophylactic group $(n=52)$ & Non-prophylactic group $(n=9)$ \\
\hline Median age, years (range) & $64(47-79)$ & $67(61-76)$ \\
\hline \multicolumn{3}{|l|}{ Gender } \\
\hline Male & $34(65 \%)$ & $5(56 \%)$ \\
\hline Female & $18(35 \%)$ & $4(44 \%)$ \\
\hline \multicolumn{3}{|l|}{ Smoking history } \\
\hline Never & $14(27 \%)$ & $4(44 \%)$ \\
\hline Ever & $38(73 \%)$ & $5(56 \%)$ \\
\hline \multicolumn{3}{|l|}{ Performance status } \\
\hline $0 / 1$ & $3 / 42(87 \%)$ & $1 / 8(100 \%)$ \\
\hline $2 / 3$ & $5 / 2(13 \%)$ & $0 / 0(0 \%)$ \\
\hline \multicolumn{3}{|l|}{ Histology } \\
\hline Adenocarcinoma & $35(67 \%)$ & $7(78 \%)$ \\
\hline Squamous/Large & $16 / 1(33 \%)$ & $2 / 0(22 \%)$ \\
\hline \multicolumn{3}{|l|}{$E G F R$ mutation } \\
\hline Mutant & $15(29 \%)$ & $3(33 \%)$ \\
\hline Wild & $37(71 \%)$ & $6(67 \%)$ \\
\hline Prior regimens, median (range) & $2(1-8)$ & $1(1-9)$ \\
\hline \multicolumn{3}{|l|}{ Prior bevacizumab } \\
\hline Administered & $21(40 \%)$ & $3(33 \%)$ \\
\hline None & $31(60 \%)$ & $6(67 \%)$ \\
\hline \multicolumn{3}{|l|}{ Prior EGFR-TKIs } \\
\hline Administered & $17(33 \%)$ & $3(33 \%)$ \\
\hline None & $35(67 \%)$ & $6(67 \%)$ \\
\hline \multicolumn{3}{|l|}{ Prior platinum doublets } \\
\hline Administered & $52(100 \%)$ & $9(100 \%)$ \\
\hline None & $0(0 \%)$ & $0(0 \%)$ \\
\hline \multicolumn{3}{|l|}{ Prior taxanes } \\
\hline Administered & $28(54 \%)$ & $5(56 \%)$ \\
\hline None & $24(46 \%)$ & $4(44 \%)$ \\
\hline
\end{tabular}

Abbreviations: EGFR, epidermal growth factor receptor; TKI, tyrosine kinase inhibitor.

remaining $9(15 \%)$ patients without primary prophylactic PEG-G-CSF (non-prophylactic group), incidence of FN was mainly examined. Patient characteristics are shown in Table 1. Among prophylactic group, median age was 64 (range, 47-79). Male (65\%), smoker (73\%), and good Eastern Cooperative Oncology Group performance status (PS) $(0 / 1)(87 \%)$ were dominant. Fifteen $(29 \%)$ were $E G F R$ mutant (no $A L K$-fusioned). Median number of prior regimens was 2 (range, $1-8$ ). Prior bevacizumab was administered in $21(40 \%)$ patients. Prior EGFR-TKIs were prescribed in all $15 E G F R$-mutant patients, and two wildtype patients underwent erlotinib. All patients received docetaxel plus ramucirumab after failure of platinumdoublets. Prior taxanes were administered in 28 (54\%) patients. Patient characteristics of non-prophylactic group were similar to prophylactic group.

\section{Incidence of febrile neutropenia}

No FN (0\%: 95\% confidence interval [CI], 0-6.9\%) was confirmed in 52 prophylactic group patients, whereas FN was observed in 3 (33\%: 95\% CI, 7.5-70.1\%) of 9 non-prophylactic group patients.

\section{Efficacy in prophylactic group}

One (1.9\%) complete response (CR), 15 (28.8\%) partial response (PR), 22 (42.3\%) stable disease (SD), 12 
(23.1\%) PD, and 2 (3.8\%) not evaluable were confirmed, resulting in $\mathrm{RR}$ of $30.8 \%(95 \% \mathrm{CI}, 18.7-45.1 \%)$ and DCR of $73.1 \%$ (95\% CI, 60.4-86.4\%), respectively. The median PFS was 4.5 (95\% CI, 3.0-6.6) months (Figure 2), and the median OS was $11.4(95 \% \mathrm{CI}, 8.0-13.9)$ months (referential results because docetaxel plus ramucirumab was administered at multiple lines).

\section{Safety in prophylactic group}

Table 2 summarizes adverse events (AEs) in 52 patients with prophylactic PEG-G-CSF. Hematological AEs $\geq$ grade 3: 6 (11.5\%) neutropenia; 3 (5.8\%) anemia; and $2(3.8 \%)$ thrombocytopenia were recorded. Nonhematological AEs $\geq$ grade $3: 7(13.5 \%)$ oral mucositis; $4(7.7 \%)$ anorexia; 2 (3.8\%) interstitial lung disease (ILD); 1 allergy (1.9\%); 1 (1.9\%) hand-foot syndrome; and $1(1.9 \%)$ neurotoxicity were observed. Ramucirumabassociated AEs zgrade 3: $1(1.9 \%)$ brain tumor hemorrhage; 1 (1.9\%) gastrointestinal bleeding; and 1 $(1.9 \%)$ venous thrombosis were found. Neither grade 4 nor 5 non-hematological AEs were confirmed.

\section{Administration of docetaxel and ramucirumab in prophylactic group}

Docetaxel was administered at $60 \mathrm{mg} / \mathrm{m}^{2}$ in 44 $(85 \%)$ patients and at $50 \mathrm{mg} / \mathrm{m}^{2}$ in $8(15 \%)$ patients (dose reduction was performed at physicians' discretion). Median cycles of docetaxel and ramucirumab was 3 (range, 1-25). Fourteen (29\%) patients received more than 6 cycles of the therapy. Three $(6 \%)$ and $9(17 \%)$ patients moved to docetaxel and ramucirumab monotherapy, respectively, because of intolerable toxicities or physicians' discretion.

\section{Characteristics of febrile neutropenia patients}

Table 3 shows data on three patients who suffered from FN. These three patients did not receive prophylactic PEG-G-CSF. All patients had good PS (ECOG PS: 1), but experienced grade 4 neutropenia. Two of 3 patients were aged $\geq 75$. Prior bevacizumab was administered in one patient. Two patients were collected from SCC and one was from $\mathrm{KCGH}$.

\section{Characteristics of elderly patients aged $\geq 75$}

Table 4 shows data on elderly patients aged $\geq 75$ ( $n=11)$. Initial dose of docetaxel was reduced to $50 \mathrm{mg} / \mathrm{m}^{2}$ in four cases at physicians' discretion. No FN was confirmed in all nine cases receiving PEG-G-CSF support, whereas two cases without PEG-G-CSF had FN. Four of these 11 patients achieved PR. AEs $\geq$ grade $2 ; 6$ mucocitis; 5 anemia; 3 thrombocytopenia; 2 neutropenia; 1 anorexia; 1 malaise; 1 hand-foot syndrome; 1 ILD; and 1 hypertension were observed.

\section{DISCUSSION}

To the best of our knowledge, this is the first report to investigate the efficacy and safety of docetaxel plus ramucirumab with primary prophylactic PEG-G-CSF support in pretreated NSCLC. Our study demonstrated $0 \%$ of FN incidence by primary prophylactic PEG-G-CSF support in docetaxel plus ramucirumab therapy for Japanese patients with pretreated NSCLC. FN incidence of REVEL and Japanese phase II study in docetaxel plus ramucirumab were $13.3 \%$ and $34.2 \%$, respectively $[13,14]$. Our study suggests high potency of primary prophylactic PEG-G-CSF support to prevent $\mathrm{FN}$ in docetaxel plus ramucirumab therapy.

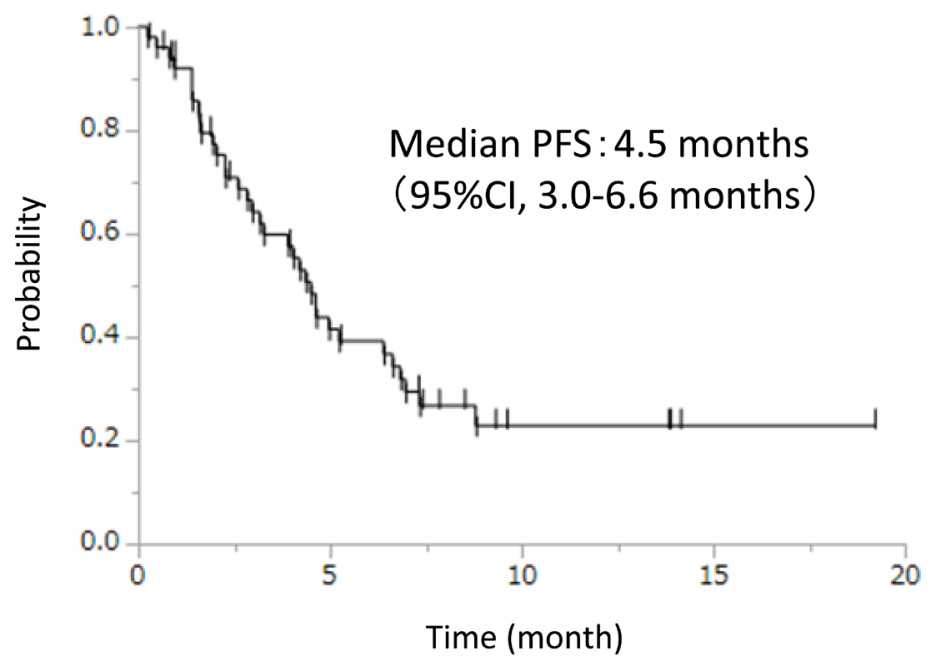

PFS, progression-free survival; $\mathrm{Cl}$, confidence interval.

Figure 2: Progression-free survival. 
Table 2: Adverse events in patients with prophylactic PEG-G-CSF $(n=52)$

\begin{tabular}{|c|c|c|c|c|}
\hline Adverse event & $\begin{array}{c}\text { Grade } 1 / 2 \\
(n)\end{array}$ & $\begin{array}{c}\text { Grade } 3 / 4 \\
\text { (n) }\end{array}$ & $\begin{array}{c}\geq \underset{(\%)}{\text { grade } 3} \\
(\%)\end{array}$ & $\begin{array}{l}\text { All } \\
(\%)\end{array}$ \\
\hline \multicolumn{5}{|l|}{ Hematological } \\
\hline Neutropenia & 10 & 6 & 11.5 & 30.8 \\
\hline Anemia & 26 & 3 & 5.8 & 55.8 \\
\hline Thrombocytopenia & 12 & 2 & 3.8 & 26.9 \\
\hline Febrile neutropenia & - & 0 & 0 & 0 \\
\hline \multicolumn{5}{|l|}{ Non-hematological } \\
\hline Anorexia & 23 & 4 & 7.7 & 51.9 \\
\hline Malaise & 18 & 0 & 0 & 34.6 \\
\hline Oral mucositis & 19 & 7 & 13.5 & 50.0 \\
\hline Interstitial pneumonia & 0 & 2 & 3.8 & 3.8 \\
\hline Neurotoxicity & 4 & 1 & 1.9 & 9.6 \\
\hline Allergy & 0 & 1 & 1.9 & 1.9 \\
\hline Hand-foot syndrome & 0 & 1 & 1.9 & 1.9 \\
\hline \multicolumn{5}{|l|}{ Ramucirumab-associated } \\
\hline Hemoptysis & 3 & 0 & 0 & 5.8 \\
\hline Epistaxis & 7 & 0 & 0 & 13.5 \\
\hline Hypertension & 7 & 0 & 0 & 13.5 \\
\hline Proteinuria & 14 & 0 & 0 & 26.9 \\
\hline Venous thrombosis & 0 & 1 & 1.9 & 1.9 \\
\hline Brain hemorrhage & 0 & 1 & 1.9 & 1.9 \\
\hline Gastrointestinal bleeding & 0 & 1 & 1.9 & 1.9 \\
\hline
\end{tabular}

No grade $4 / 5$ adverse events

Abbreviations: PEG-G-CSF, pegylated-granulocyte-colony stimulating factor.

The RR and DCR in prophylactic group were $30.8 \%$ and $73.1 \%$, respectively. These results were comparable to REVEL (23\% and 64\%) and Japanese phase II study (28.5\% and $78.9 \%)$ in each docetaxel plus ramucirumab arm $[13,14]$. The median PFS was 4.5 months, which was also similar to that of REVEL (4.5 months) and Japanese phase II study (5.2 months) [13, 14]. Although our study population included relatively many heavily pretreated patients, primary prophylactic PEG-G-CSF support improved the safety while maintaining the effectiveness in docetaxel plus ramucirumab therapy.

Neither grade 4 nor 5 non-hematological AEs were confirmed, owing to primary prophylactic PEG-GCSF support, with neutropenia $\geq$ grade 3 only observed in $6(11.5 \%)$ patients. Some ramucirumab-associated AEs $\geq$ grade 3 were confirmed: $1(1.9 \%)$ brain tumor hemorrhage; 1 (1.9\%) gastrointestinal bleeding; and 1 $(1.9 \%)$ venous thrombosis. Incidences of these VEGFassociated AEs were not high, compared to historical data of docetaxel plus ramucirumab therapy [13, 14]. Oral mucositis was the only non-hematological AEs $\geq$ grade 3 observed more than $10 \%$ of patients. Physicians should beware of this $\mathrm{AE}$ for heavily pretreated patients receiving docetaxel plus ramucirumab therapy in clinical practice.

The study populations included 11 patients aged $\geq 75$. No FN was confirmed in all nine cases receiving PEGG-CSF support, whereas two cases without PEG-G-CSF had FN. Moreover, four of these nine patients achieved PR, and general AEs were tolerable. Although docetaxel dose was reduced to $50 \mathrm{mg} / \mathrm{m}^{2}$ in a 76 year-old male, FN was confirmed with grade 4 neutropenia. Administration of PEG-G-CSF seems a better option than dose reduction. PEG-G-CSF support might be much more reasonable for elderly patients receiving docetaxel plus ramucirumab. Indeed, a multicenter phase II trial to evaluate the efficacy and safety of docetaxel plus ramucirumab with PEG-GCSF support for chemo-naïve elderly NSCLC patients is ongoing (West Japan Oncology Group 9416L).

Our study was retrospective and small sample size, including several limitations. Regular measurement of temperature was not routinely carried out. FN incidence might have been estimated lower. However, FN is generally considered as an oncology emergency, and clinically relevant FN must have been detected. Tumor 
Table 3: Characteristics of febrile neutropenia patients $(n=3)$

\begin{tabular}{|c|c|c|c|c|c|c|c|c|c|c|c|c|c|}
\hline Age & Sex & His & PS & EGFR & Smoking & $\begin{array}{l}\text { DOC } \\
\text { dose }\end{array}$ & $\begin{array}{l}\text { PEG- } \\
\text { G-CSF }\end{array}$ & $\begin{array}{c}\text { Line of } \\
\text { DOC + } \\
\text { RAM }\end{array}$ & $\begin{array}{l}\text { Prior } \\
\text { Bev }\end{array}$ & Institute & Response & PFS & $\begin{array}{l}\text { Adverse events } \\
\quad(\text { grade } \geq 2)\end{array}$ \\
\hline 63 & M & Ad & 1 & Wild & Former & 60 & - & 2nd & + & $\mathrm{SCC}$ & SD & 1.9 & Neutropenia (G4) \\
\hline 75 & M & Ad & 1 & Wild & Former & 60 & - & 2nd & - & $\mathrm{SCC}$ & PD & 1.8 & $\begin{array}{l}\text { Neutropenia (G4), } \\
\text { anemia (G2), } \\
\text { thrombocytopenia } \\
(\mathrm{G} 2) \text {, anorexia } \\
\text { (G2), mucositis } \\
\text { (G2) }\end{array}$ \\
\hline 76 & M & Ad & 1 & L858R & Never & 50 & - & 4 th & - & $\mathrm{KCGH}$ & $\mathrm{NE}$ & 1.0 & $\begin{array}{l}\text { Neutropenia (G4) } \\
\text { mucositis (G2) }\end{array}$ \\
\hline
\end{tabular}

Abbreviations: His, histology; PS, performance status; EGFR, epidermal growth factor receptor; DOC, docetaxel; PEG-G-CSF, pegylatedgranulocyte-colony stimulating factor; RAM, ramucirumab; Bev, bevacizumab; SCC, Shikoku Cancer Center; KCGH, Kobe City Medical Center General Hospital; PFS, progression-free survival; M, male; F, female; Ad, adenocarcinoma; SD, stable disease; PD, progressive disease; NE, not evaluable; G, grade; ILD, interstitial lung disease.

Table 4: Characteristics of elderly patients aged $\geq 75(n=11)$

\begin{tabular}{|c|c|c|c|c|c|c|c|c|c|c|c|c|}
\hline Age & Sex & His & PS & EGFR & Smoking & $\begin{array}{l}\text { DOC } \\
\text { dose }\end{array}$ & $\begin{array}{l}\text { PEG- } \\
\text { G-CSF }\end{array}$ & $\begin{array}{l}\text { Line of DOC } \\
+ \text { RAM }\end{array}$ & $\mathbf{F N}$ & Response & PFS & Adverse events (grade $\geq 2$ ) \\
\hline 75 & $\mathrm{M}$ & Ad & 1 & Wild & Former & 60 & + & 2nd & - & PR & 2.4 & Anemia (G2) \\
\hline 75 & $\mathrm{~F}$ & $\mathrm{Sq}$ & 1 & Wild & Never & 50 & + & 7 th & - & SD & 4.4 & Thrombocytopenia (G3) \\
\hline 75 & M & Ad & 1 & Wild & Former & 60 & - & 2nd & + & PD & 1.8 & $\begin{array}{c}\text { Neutropenia }(\mathrm{G} 4) \text {, anemia } \\
(\mathrm{G} 2) \text {, thrombocytopenia }(\mathrm{G} 2), \\
\text { anorexia }(\mathrm{G} 2) \text {, mucositis }(\mathrm{G} 2)\end{array}$ \\
\hline 76 & M & $\mathrm{La}$ & 1 & Wild & Former & 60 & + & $3 \mathrm{rd}$ & - & SD & 2.6 & $\begin{array}{c}\text { Anemia }(\mathrm{G} 2), \\
\text { thrombocytopenia }(\mathrm{G} 2), \\
\text { anorexia }(\mathrm{G} 2), \text { mucositis } \\
(\mathrm{G} 2), \text { malaise }(\mathrm{G} 2), \text { hand-foot } \\
\text { syndrome }(\mathrm{G} 3)\end{array}$ \\
\hline 76 & M & Ad & 1 & L858R & Former & 60 & + & 7 th & - & SD & 2.1 & Anemia (G2) \\
\hline 76 & M & Ad & 1 & L858R & Never & 50 & - & 4 th & + & $\mathrm{NE}$ & 1.0 & $\begin{array}{l}\text { Neutropenia (G4), mucositis } \\
\text { (G2) }\end{array}$ \\
\hline 77 & M & $\mathrm{Sq}$ & 1 & Wild & Former & 60 & + & $3 \mathrm{rd}$ & - & PR & $19.2+$ & Hypertension (G2) \\
\hline 78 & M & $\mathrm{Sq}$ & 1 & Wild & Former & 60 & + & $3 \mathrm{rd}$ & - & PR & $7.3+$ & Mucositis (G2) \\
\hline 78 & $\mathrm{~F}$ & Ad & 1 & Del-19 & Never & 50 & + & $3 \mathrm{rd}$ & - & PR & 6.6 & Anemia (G2), ILD (G3) \\
\hline 79 & $\mathrm{~F}$ & Ad & 1 & Wild & Never & 50 & + & $3 \mathrm{rd}$ & - & SD & $7.4+$ & Mucositis (G2) \\
\hline 79 & $\mathrm{~F}$ & Ad & 2 & Wild & Never & 60 & + & 2nd & - & SD & $8.5+$ & Mucositis (G2) \\
\hline
\end{tabular}

Abbreviations: His, histology; PS, performance status; EGFR, epidermal growth factor receptor; DOC, docetaxel; PEG-G-CSF, pegylated-granulocyte-colony stimulating factor; RAM, ramucirumab; FN, febrile neutropenia; PFS, progression-free survival; M, male; F, female; Ad, adenocarcinoma; Sq, squamous cell carcinoma; La, large cell carcinoma; PR, partial response; SD, stable disease; PD, progressive disease; NE, not evaluable; G, grade; ILD, interstitial lung disease.

response and PFS were evaluated using the Response Evaluation Criteria in Solid Tumors (RECIST), but durations of CT scans depended on doctors in charge. These variable durations could be a bias of our study. However, purpose of chemotherapy for pretreated patients was not response, but living longer with better quality of life (QOL). Subset analysis of the Japanese phase II trial suggested a possible association between FN occurrence and QOL deterioration [14, 17]. PEG-G-CSF support could maintain QOL in pretreated patients receiving docetaxel plus ramucirumab therapy.
In conclusion, our study demonstrated $0 \%$ of $\mathrm{FN}$ incidence by primary prophylactic PEG-G-CSF support in docetaxel plus ramucirumab therapy for Japanese patients with pretreated NSCLC. Primary prophylactic PEG-G-CSF could markedly reduce incidence of FN. Our study populations included many heavily pretreated patients, while docetaxel plus ramucirumab showed notable efficacy and safety. Further studies are warranted to confirm the effectiveness of primary prophylactic PEG-G-CSF support in docetaxel plus ramucirumab therapy. 


\section{METHODS}

\section{Patients}

This is a retrospective study of two institutes. We screened all NSCLC patients to identify cases who had received docetaxel plus ramucirumab in Department of Medical Oncology, KCGH and Department of Thoracic Oncology, SCC. Patients' results were collected using electric medical and radiographic records to take clinical information: age; gender; smoking history; PS; histology; $E G F R$-mutation or $A L K$-fusion status; prior therapies before docetaxel plus ramucirumab; and clinical course details. We evaluated the RR, DCR, PFS, OS, and safety, especially FN. This study was approved by the institutional review board of each institute.

\section{Treatment}

Intravenous docetaxel $\left(60 \mathrm{mg} / \mathrm{m}^{2}\right.$, day 1) plus intravenous ramucirumab $(10 \mathrm{mg} / \mathrm{kg}$, day 1$)$ with subcutaneous PEG-G-CSF (3.6 mg, day 2) every 3 weeks was administered until progression or unacceptable toxicities. Initial docetaxel dose of some cases was reduced to $50 \mathrm{mg} / \mathrm{m}^{2}$ by the discretion of physicians in charge. In cases with intolerable toxicities, docetaxel dose was reduced to $50 \mathrm{mg} / \mathrm{m}^{2}, 40 \mathrm{mg} / \mathrm{m}^{2}$, or $30 \mathrm{mg} / \mathrm{m}^{2}$. Furthermore, docetaxel or ramucirumab monotherapy was administered when intolerable toxicities occurred but clinical benefit was obtained by each drug.

Tumor evaluations were performed every $6-9$ weeks with computed tomography.

\section{Statistical analysis}

Tumor response was evaluated in accordance with the RECIST (version 1.1). The DCR was defined as the rate of $\mathrm{CR} / \mathrm{PR}+\mathrm{SD} \geq 6$ weeks in our study. The PFS was calculated from the date of therapy initiation to disease progression or death. The OS was calculated from the date of therapy initiation to death, and censored at the date of last visit for patients whose deaths could not be confirmed. PFS and OS were analyzed using the KaplanMeier method to estimate the median points with $95 \%$ CI. Toxicity was assessed according to the National Cancer Institute Common Terminology Criteria for Adverse Events (version 4.0). The statistical analyses were performed using JMP 12 (SAS Institute, Inc., Cary, NC, USA).

\section{Author contributions}

Study concept, AH, DH, NN, and NK; Study design, $\mathrm{AH}$ and $\mathrm{DH}$; Data acquisition, $\mathrm{AH}$ and $\mathrm{DH}$; Quality control of data and algorithms; $\mathrm{AH}$ and DH; Data analysis and interpretation, $\mathrm{AH}, \mathrm{DH}, \mathrm{NN}$, and NK; Statistical analysis, $\mathrm{AH}$ and $\mathrm{DH}$; Manuscript preparation, $\mathrm{AH}$ and DH; Manuscript editing, AH and DH; Manuscript review, all authors.

\section{ACKNOWLEDGMENTS}

We thank Ayami Asakawa, Mizuho Awaki, Suemi Minamihara, Hiroko Ishikawa and Mamiya Atagi for their assistance, and Mr. David Martin for writing support.

\section{CONFLICTS OF INTEREST}

Akito Hata received lecture fee from Chugai, Astra Zeneca, Boeringer Ingelheim, and Eli Lilly. Daijiro Harada has received lecture fees from Ono, Bristol-Myers Squibb, Yakult Honsha, Kyowa Hakko Kirin, AstraZeneca, Nippon Boehringer Ingelheim and Eli Lilly Japan. Toshiyuki Kozuki has received honoraria from Chugai, AstraZeneca, Eli Lilly Japan, Boehringer-Ingelheim, Ono, BristolMyers Squibb, Taiho, MSD, Pfizer and Kyowa Hakko Kirin, and research funding from Chugai, AstraZeneca, MSD, and Eli Lilly Japan. Naoyuki Nogami has received honoraria from Astellas, AstraZeneca, Ono, Taiho, Chugai, Eli Lilly, Boehringer Ingelheim and Pfizer. Nobuyuki Katakami received grants from Astra Zeneca, Eisai, Ono, Kyowa Kirin, Shionogi, Daiichi-Sankyo, Taiho, Chugai, Eli Lilly, Boeringer Ingelheim, and Merck Serono, and payment for lectures from Dainippon Sumitomo, Chugai, Boeringer Ingelheim, Astra Zeneca, Eli Lilly, Taiho, Janssen, Novartis, Pfizer, Ono, and Daiichi-Sankyo. The other authors declare no conflicts of interest.

\section{GRANT SUPPORT}

None.

\section{REFERENCES}

1. Lynch TJ, Bell DW, Sordella R, Gurubhagavatula S, Okimoto RA, Brannigan BW, Harris PL, Haserlat SM, Supko JG, Haluska FG, Louis DN, Christiani DC, Settleman $\mathrm{J}$, et al. Activating mutations in the epidermal growth factor receptor underlying responsiveness of non-small-cell lung cancer to gefitinib. N Engl J Med. 2004; 350:2129-2139.

2. Paez JG, Janne PA, Lee JC, Tracy S, Greulich H, Gabriel S, Herman P, Kaye FJ, Lindeman N, Boggon TJ, Naoki K, Sasaki H, Fujii Y, et al. EGFR mutations in lung cancer: correlation with clinical response to gefitinib therapy. Science. 2004; 304:1497-1500.

3. Soda M, Choi YL, Enomoto M, Takada S, Yamashita Y, Ishikawa S, Fujiwara S, Watanabe H, Kurashina K, Hatanaka H, Bando M, Ohno S, Ishikawa Y, et al. Identification of the transforming EML4-ALK fusion gene in non-small-cell lung cancer. Nature. 2007; 448:561-566. 
4. Lee CK, Wu YL, Ding PN, Lord SJ, Inoue A, Zhou C, Mitsudomi T, Rosell R, Pavlakis N, Links M, Gebski V, Gralla RJ, Yang JC. Impact of Specific Epidermal Growth Factor Receptor (EGFR) Mutations and Clinical Characteristics on Outcomes After Treatment With EGFR Tyrosine Kinase Inhibitors Versus Chemotherapy in EGFRMutant Lung Cancer: A Meta-Analysis. J Clin Oncol. 2015; 33:1958-1965.

5. Solomon BJ, Mok T, Kim DW, Wu YL, Nakagawa K, Mekhail T, Felip E, Cappuzzo F, Paolini J, Usari T, Iyer S, Reisman A, Wilner KD, et al; PROFILE 1014 Investigators. First-line crizotinib versus chemotherapy in ALK-positive lung cancer. N Engl J Med. 2014; 371:2167-2177.

6. Reck M, Rodríguez-Abreu D, Robinson AG, Hui R, Csőszi T, Fülöp A, Gottfried M, Peled N, Tafreshi A, Cuffe S, O'Brien M, Rao S, Hotta K, et al; KEYNOTE-024 Investigators. Pembrolizumab versus Chemotherapy for PD-L1-Positive Non-Small-Cell Lung Cancer. N Engl J Med. 2016; 375:1823-1833.

7. Brahmer J, Reckamp KL, Baas P, Crinò L, Eberhardt WE, Poddubskaya E, Antonia S, Pluzanski A, Vokes EE, Holgado E, Waterhouse D, Ready N, Gainor J, et al. Nivolumab versus Docetaxel in Advanced SquamousCell Non-Small-Cell Lung Cancer. N Engl J Med. 2015; 373:123-135.

8. Borghaei H, Paz-Ares L, Horn L, Spigel DR, Steins M, Ready NE, Chow LQ, Vokes EE, Felip E, Holgado E, Barlesi F, Kohlhäufl M, Arrieta O, et al. Nivolumab versus Docetaxel in Advanced Nonsquamous Non-Small-Cell Lung Cancer. N Engl J Med. 2015; 373:1627-1639.

9. Herbst RS, Baas P, Kim DW, Felip E, Pérez-Gracia JL, Han JY, Molina J, Kim JH, Arvis CD, Ahn MJ, Majem M, Fidler MJ, de Castro G Jr, et al. Pembrolizumab versus docetaxel for previously treated, PD-L1-positive, advanced non-small-cell lung cancer (KEYNOTE-010): a randomised controlled trial. Lancet. 2015; 387:1540-1550.

10. Rittmeyer A, Barlesi F, Waterkamp D, Park K, Ciardiello F, von Pawel J, Gadgeel SM, Hida T, Kowalski DM, Dols MC, Cortinovis DL, Leach J, Polikoff J, et al; OAK Study Group. Atezolizumab versus docetaxel in patients with previously treated non-small-cell lung cancer (OAK): a phase 3, open-label, multicentre randomised controlled trial. Lancet. 2017; 389:255-265.

11. Inoue $T$, Tamiya M, Tamiya A, Nakahama K, Taniguchi $Y$, Shiroyama T, Isa SI, Nishino K, Kumagai T, Kunimasa K,
Kimura M, Suzuki H, Hirashima T, et al. Analysis of Early Death in Japanese Patients With Advanced Non-small-cell Lung Cancer Treated With Nivolumab. Clin Lung Cancer. 2017; 17:30274-30277.

12. Spratlin JL, Cohen RB, Eadens M, Gore L, Camidge DR, Diab S, Leong S, O’Bryant C, Chow LQ, Serkova NJ, Meropol NJ, Lewis NL, Chiorean EG, et al. Phase I pharmacologic and biologic study of ramucirumab (IMC1121B), a fully human immunoglobulin G1 monoclonal antibody targeting the vascular endothelial growth factor receptor-2. J Clin Oncol. 2010; 28:780-787.

13. Garon EB, Ciuleanu TE, Arrieta O, Prabhash K, Syrigos KN, Goksel T, Park K, Gorbunova V, Kowalyszyn RD, Pikiel J, Czyzewicz G, Orlov SV, Lewanski CR, et al. Ramucirumab plus docetaxel versus placebo plus docetaxel for second-line treatment of stage IV non-small-cell lung cancer after disease progression on platinum-based therapy (REVEL): a multicentre, double-blind, randomised phase 3 trial. Lancet. 2014; 384:665-673.

14. Yoh K, Hosomi Y, Kasahara K, Yamada K, Takahashi T, Yamamoto N, Nishio M, Ohe Y, Koue T, Nakamura T, Enatsu S, Lee P, Ferry D, et al. A randomized, double-blind, phase II study of ramucirumab plus docetaxel vs placebo plus docetaxel in Japanese patients with stage IV non-small cell lung cancer after disease progression on platinum-based therapy. Lung Cancer. 2016; 99:186-193.

15. Smith TJ, Khatcheressian J, Lyman GH, Ozer H, Armitage JO, Balducci L, Bennett CL, Cantor SB, Crawford J, Cross SJ, Demetri G, Desch CE, Pizzo PA, et al. 2006 update of recommendations for the use of white blood cell growth factors: an evidence-based clinical practice guideline. J Clin Oncol. 2006; 24:3187-3205.

16. Kosaka Y, Rai Y, Masuda N, Takano T, Saeki T, Nakamura S, Shimazaki R, Ito Y, Tokuda Y, Tamura K. Phase III placebo-controlled, double-blind, randomized trial of pegfilgrastim to reduce the risk of febrile neutropenia in breast cancer patients receiving docetaxel/ cyclophosphamide chemotherapy. Support Care Cancer. 2015; 23:1137-1143.

17. Omori Y, Brnabic A, Rajan N, Park J, Enatsu S, Inoue A. QOL and Febrile Neutropenia: Japanese Phase 2 Trial of Docetaxel with/out Antiangiogenic Agent in 2nd Line NSCLC. J Thorac Oncol. 2017; 12:S901. (abstr: P2.03a-022). 